\title{
A Bourdieuan Analysis of the Toledo School and Gerard of Cremona
}

\author{
Toledo Okulu ve Cremonalı Gerard’ın Bourdieucü Analizi
}

\author{
Research/Araştırma
}

\section{Cemal TOPCU}

Research Assistant, Istanbul Aydın University, School of Foreign Languages Department of Translation \& Interpreting, cemaltopcu@aydin.edu.tr, ORCID ID: https://orcid.org/0000-0002-2524-463X

\begin{abstract}
Using the Bourdieuan thinking tools to analyze a historically important translation movement and its leading translator might demonstrate how a field creates the necessary environment for such a period of intense translation activity and how a person comes to be a leading figure in this movement. This paper discusses the Toledo Translation School and Gerard of Cremona from a sociological perspective by collecting data from biographies, articles and books about the era and Gerard himself. The results show that Gerard, educating himself on the limited knowledge that his hometown could offer, comes to Toledo in order to accumulate more cultural capital. In Toledo, the conditions of the field form the necessary environment that a translation movement requires. Through his habitus and cultural, symbolic and social capitals, Gerard came to the forefront of this movement. Furthermore, his high cultural capitals earn a scarcity value, which contributes to make him a dominant figure in his field. This analysis demonstrates that a sociological perspective to translation history can reveal more about the background of translation movements and prominent translators involved in them.
\end{abstract}

Keywords: Toledo Translation School, Gerard of Cremona, Pierre Bourdieu, habitus, capital, field.

\section{ÖZET}

Tarihi açıdan önemli bir çeviri hareketini ve bu hareketin öncü çevirmenlerini incelemek için Bourdieucü düşünme araçlarını kullanmak, bir alanın böylesine yoğun bir çeviri dönemi için gerekli ortamı nasıl oluşturduğunu ve bir kişinin nasıl söz konusu hareketin içinde öncü bir figür haline geldiğini gösterebilir. Bu çalışma Toledo Çeviri Okulu ve Cremonalı Gerard'ı sosyolojik bir bakış açısıyla tartışmaktadır. Bunu yaparken de dönem ve Gerard'ın kendisi hakkındaki biyografiler, makaleler ve kitaplardan faydalanılmıştır. Çalışmanın sonuçları göstermiştir ki kendini doğduğu 
yerin sunabileceği bilgilerle eğiten Gerard daha fazla kültürel sermaye edinebilmek için Toledo'ya gelir. Toledo'da ise alanın koşulları bir çeviri hareketinin ihtiyaç duyacağı ortamı yaratır. Habitusu ve kültürel, sembolik ve sosyal sermayeleri sayesinde Gerard bu harekette ön plana çıkar. Dahası, sahip olduğu yüksek kültürel sermaye, onu kendi alanında baskın bir kişi haline getiren nadirlik değerine sahiptir. Gerard örneği açık bir şekilde göstermiştir ki çeviri tarihine yönelik sosyolojik bir bakış açısı çeviri hareketlerinin arka planı ve bu hareketlerde öne çıkan çevirmenler hakkında daha fazla bilgiyi açığa çıkarabilir.

Anahtar Sözcükler: Toledo Çeviri Okulu, Cremonalı Gerard, Pierre Bourdieu, habitus, sermaye, alan

\section{Introduction and Literature Review}

Pierre Bourdieu (2005) believes that looking at the things that have been said or happened is not sufficient to understand social interactions, and he argues that studying the social space in which interactions take place is a necessity to comprehend them ( $p$. 148). Discussing a historically prominent person from the perspective of Bourdieu's thinking tools might help one to understand the general social conditions of the field as well as that person's social actions. This approach has been used for analyzing the actions of many important figures from different fields, and it can well be applied to a historically significant translator. Furthermore, the study of habitus and capital of a significant translator and the established conditions of the field that the translator is a part of might be valuable both for understanding the individual translational actions and for the general study of the history of translation. For this concern, this paper will discuss one of the most important translation schools, Toledo, and a prolific translator who was a member of this school, Gerard of Cremona (1114-1187), in the context of the notions of field, habitus and capitals. The aim of this study is to examine how the conditions of the field enabled or required such an intense translation movement and how the background and assets of Gerard affected his actions and position in the field.

So far research about the Toledo School has either been a part of studies on dissemination of knowledge and cultural exchange through translation on the way to Renaissance (Delisle \& Woodsworth, 1998; Sungu, 1940; Öztunalı, 2017), or it has been studied in terms of its translators. Although these studies involve several translators from Toledo, they tend to take Gerard to the forefront and approach the translators of the Toledo School in terms of their translation strategies and programs, quality of the translations and their terminological contributions. For instance, Charles Burnett (2001) studies mainly two translators from Toledo, Gerard of Cremona and Dominicus Gundissalinus. In his article, Burnett claims that Gerard followed a visible agenda for his translations and adopted a strategy to create a plain and comprehensible target text. He also demonstrates that different topics were studied by different translators during this Spanish translation movement. For example, the philosophical works of Avicenna were translated by Gundissalinus, works of astronomy and medicine were in the hands of Gerard, and John of Seville was responsible for texts on astrology. By this clear division, 
Burnett proves that there was "a sense of order" in the Toledo school as a whole (2001, p. 269).

Unlike Burnett, some researchers prefer to study the translations of Toledo translators in terms of quality by means of textual analysis and comparison. One of these studies was carried out by Michael W. Weber (2002). Weber compared the translations of al-Farabi's Enumeration by Gerard to the translations of the same texts by Gundissalinus, and evaluated Gerard's knowledge in the subtopics of this work, which are "1) the science of language, 2) the science of logic, 3) the mathematical sciences, 4) sciences of physics and metaphysics, and, finally, 5) law, theology, political science" (p. 126-127). He argues that while Gerard's translations in the first and last subject area were troubled, philosophy and metaphysics were his strong sides. Although Weber views Gerard's translations in these subject areas as reliable, the article mainly focuses on the problems of his translations in other subject areas, and Weber goes as far as claiming that Gerard had an obvious "unconcern for the meaning of the Latin he produced" and sometimes "his translation appears to me to be like the work of a hurried undergraduate student" (p. 131). However, there are works that promote Gerard's translations. For example, Arráez-Aybar et al. (2015) study Gerard in terms of his contributions to anatomical terminology. They claim that prominent writers of anatomical works in Latin, such as Albertus Magnus and Mondino de Luzzi, took Gerard's translations as the basis for their books. They further state that the terms coined by him, such as diaphragm, orbit and sagittal, are still used in the field (Arráez-Aybar et al., 2015, p. 32).

As it can be seen, there are several studies regarding the Toledo School, its period and its translators, including Gerard of Cremona. However, the gap where the current study is positioned is the intersection of the disciplines of Sociology and the Translation History. Some sociological research on translation history dwells upon the role of translators as social agents in the emergence of genres in specific nations (Gouanvic, 1997; Hanna, 2005; Hanna, 2016). However, the formation of literary genres is not within the scope of this paper. Therefore, it is more relevant to discuss the studies that examine historically important translators using a Bourdieuan approach. One of these studies, conducted by Jinyu Liu (2012), discusses the social environment of China in the 1900s by employing Bourdieu's notion of field, and Yan Fu, an important translator of the period, through analyzing his habitus. By scrutinizing the conditions of the period and the translational choices of Yan, Liu argues that there was a relationship of mutual structuring between Fu's habitus and the cultural field of China of that period. As the social and political conditions developed his habitus through influencing his choices of the source text, purposes for translation and strategies, his habitus as a translator informed Chinese people, who are the agents forming the social field of China. Like Liu, Sayols (2018) studies the translator Dai Wangshu in terms of his habitus formed just a few decades later in Republican China. However, agreeing with the criticisms of Bourdieu's sociology being too deterministic, Sayols integrates transculturation into the 
Bourdieuan approach and carries out a textual analysis to reveal the different strategies that were the result of "generative and inventive features of transculturation" (p. 280).

Research in the field of sociological translation history either discusses a period of cultural innovations in a nation or the importation of genres while considering translators as social agents. The above-mentioned sociological studies stick to the translators whose effect were only regional, and there seems to be no such study on historically important translational movements in the world history and the leading translators of these movements. As opposed to this approach, Daniel Simeoni (2007) states that so far mainly the prominent figures were studied in translation research, but the peripheral figures constitute the big part of cases and argues that the study of translators who, as agents, are at the periphery of their field could reveal competing norms and open new territories to discussion. For this concern, he analyzes an obscure figure in the Italian literary field, Domenico Valentini, who was also the first translator of Shakespeare's Julius Caesar (1599) into Italian. Simeoni's proposition would indeed be beneficial to find the norms that are competing with the dominant ones. However, finding the necessary sources to account for such a figure in the $12^{\text {th }}$ century Spain goes beyond the scope of this paper. Instead, this paper discusses Gerard of Cremona, a leading translator in one of such movements, the Toledo School. The reason why this period was chosen is that the era was a sort of gateway to European enlightenment. Haskins (1927) refers to this period as "The Renaissance of the 12th Century" and regards Spain as the "chief link" between the knowledge of the Arab world and Europe with its school of translation (p. 11). However, translators of this early Renaissance are not credited enough, and Berman (1989) refers to them as the "forgotten ones" (as cited in Delisle \& Woodsworth, 1998, p. 110). In order to shed light on an important architect of this movement, Gerard is chosen to be a subject of a Bourdieuan analysis since he was the most prolific translator of the period with 71 translations. Some sources state that it was even higher (McVaugh, 1974). With this amount of translated works, he was referred to as "perhaps the greatest translator of all time" (Van Hoof, 1986, as cited in Pym, 1998b, p. 41). Therefore a sociological study involving both the era, the Toledo School and Gerard would not only reveal how such an intense translation movement occurs in a field and how a translator comes to be a central figure in this field with his or her social actions, but it also would fill a significant gap between sociological studies and historical translation research.

\section{Methodology}

The three major, perhaps inseparable, thinking tools of Bourdieu, i.e. field, habitus and capital, can be quite helpful in translation studies research. In order to discuss Gerard from a Bourdieuan perspective, sources such as biographies, articles or dissertations regarding the Toledo School and its translators, books and historical documents on that period are reviewed. Fortunately, this movement in Spain paved the way to the Renaissance, thus it is an important era, and therefore discussed in some works on 
Renaissance, too. Furthermore, thanks to his contributions to various fields such as astronomy, medicine and philosophy, Gerard of Cremona is mentioned in texts from different disciplines. By benefitting from these various disciplines, sufficient data for a comprehensive analysis of Gerard's habitus, capitals and field is collected from various sources. However, some of these primary sources were in Spanish; therefore, secondary sources in English needed to be consulted.

\section{Discussion}

\subsection{Field}

Bourdieu and Wacquant (1992) define field as "a network, or a configuration, of objective relations between positions" and it sets some limits to its agents (p. 97). Furthermore, Bourdieu (1984) states that practice is a result of the unconscious relationship between a person's habitus and capitals under the general conditions of that field (p. 95). Therefore, in order to understand the social actions of Gerard as a translator, first it is necessary to understand not only the current state of the cultural field where he was actively involved as an agent, but also its development which paved the way for the Spanish translation movement and induced Gerard to leave Italy and go to Toledo for his scholarly studies (Lemay, 1985, p. 422). This section will discuss the general cultural field of the Iberian peninsula regarding its developments that attracted Gerard and provided the necessary conditions for him to take a central position in it.

The Reconquista period (718-1492) in Spain, which refers to Christians' gradually "reconquering" the peninsula from Islamic rule, involved a long period of coexistence of different cultural groups with Arabic and Romance languages (Pym, 1998 b, p. 552). This fact alone makes translation a daily necessity of life for communication during this period. However, this translation activity turned into a movement thanks to the availability of Greek and Arab knowledge in the region through the Umayyad Caliphate. According to Baker (1998), the Arabic translation movement of Greek scientific works, which started in Bayt al-Hikma in 830 with the patronage of alMansur, the seventh Abbasid caliph, made it possible for Greek scientific works to travel to Spain through an offshoot of the Umayyad Caliphate whose capital was established in Cordoba. When the Reconquista reached Cordoba, Muslims took refuge in the city of Toledo, where they lived with Jewish people and Mozarabs, a name given to the Christians in the Iberian peninsula who lived under the rule of Muslims (Burnett, 2001, p. 249). This multicultural environment in Toledo was definitely one of the factors that supported the translation movement of the twelfth century. However, perhaps the main reason behind this translation movement was the imbalance between Arabic Spain and Christian Spain in terms of knowledge. While there were 570 books in the library of the order of Cluni in Sahagún, which was regarded as "a remarkable large and complete collection for its time" (Haskins, 1927, p. 43), Toledo had 300.000 Arabic works (Werrie, 1969 , as cited in Delisle \& Woodsworth, 1998, p. 111). This imbalance must have pushed Christians to learn the wisdom of the Arabs, who gradually fell under their rule. One 
evidence for this is that scholars from all around the West, such as Herman of Carinthia, Robert of Ketton and Gerard of Cremona, came to the region in order to search out this Arabic science. The knowledge they encountered was so vast that they stayed in Toledo to learn Arabic and transmit this knowledge into Latin (Pym, 1998a, p. 99).

Although there were some unorganized translation efforts previously in the region, this act of translation became a movement after the reconquest of Toledo in 1085, and Mozarabs and Jews in the region were at the foundation of this intense translation period, which later drew scholars from all Europe (Haskins, 1927, p. 52). After the reconquest, Raymond, the archbishop of the Toledo cathedral, initiated the foundation of the Toledo Translation School around 1130 (Arráez-Aybar et al., 2015, p. 23). Although it came to be called a translation school, Toledo was not a formal institution of translation like Bayt al-Hikma. Weber (2019) states that the Toledo Translation School "was rather an aggregation of effort based upon dozens of individual choices and diverse opportunities", and each translator "was driven with his own agenda" (p. 396). Nevertheless, how these individual endeavors created a movement that embraces different efforts with different goals is another question. Weber (2019) believes that it was their "common intellectual tradition" that resulted in a "unified character of translation" at the time (p. 396). Indeed, while translators and patrons might have had their own agenda, there was one thing all these efforts had in common: transmitting the Arabic wisdom to the realm of Christianity. Therefore, it would not be wrong to group these separate endeavors around the city of Toledo into a single translation movement and refer to them as a translation school.

To give an example of how patrons pursued different aims through translation, Raymond would commission translations with the primary interest of reforming the Church rather than promoting scientific learning (Delisle \& Woodsworth, 1998, p. 250). However, the amount and variety of subjects of Arabic texts were so vast that translations could not be limited to a religious goal. Eventually, the philosophical translations completed during Raymond's period were followed by those of works of medicine, mathematics and astronomy, and this led to a different approach to this translation movement under the patronage of the Castilian King Alfonso $\mathrm{X}$, who sponsored the translation of Arabic scientific texts into Castilian vernacular with a goal of nation-building (Pym, 1998b, p. 553). What these two patrons of translation had in common was that they both turned to the knowledge of the Arabs to accomplish their aim. Numerous efforts with diverse objectives, all turning to Arabic as a source language and rendering the works into Romance languages, created a flow of knowledge with a certain direction and resulted in each being a part of a vast translation movement.

As it is seen, the cultural field of the period consisting of agents with different languages led to dependence on translation as a means of communication. The Arabic cultural field was so powerful that it urged Christians to learn from their knowledge through translation, and this was the main factor in the field that led to an intense translation movement; thus, it can be stated that the neighboring fields affected each other. The patrons with different agendas also facilitated this translation movement. 
Additionally, as a result of the multicultural environment, bilingual agents were available, and their influence cannot be overemphasized. With all these developments considered, it could be stated that the existing and changing conditions of the cultural field not only made translation practicable but also essential. When Gerard came into this field and aspired to translate the Arabic scientific works, the current environment was already in favor of him. As he continued to produce new translations in diverse subjects such as mathematics, medicine and astronomy, he claimed a central position in the scientific field of the period. Moreover, his contributions to the European scholarship with translations of Aristotle also brought him a significant position in the philosophical field. Aside from Gerard's central position, these fields were dominant among other fields, as well. What earned them importance in the era was their recent and fast formation. Furthermore, as indicated previously, the knowledge transmitted from Arabic into Latin was mostly unknown to the target culture. Thus, the scientific and philosophical fields in which Gerard's translations were situated gained in importance.

\subsection{Habitus}

The formulation of social actions also includes the factor of personal habitus as discussed above. Bourdieu (1977) defines habitus as 'an acquired system of generative schemes objectively adjusted to the particular conditions in which it is constituted" (p. 95). For Bourdieu (1993), since social actions are not calculated, they are rather results of "an unconscious relationship between a habitus and a field" (p. 76). Therefore, studying the background of Gerard, his education and upbringing, i.e. his habitus, will definitely help reveal the factors behind his position in the field and his practices as a translator. As his name clearly indicates, Gerard (1114-1187) was born in Cremona, Italy. Therefore, Italian was his native language, and of course, he also knew Latin since it was the target language of his translations. He received education in schools of philosophy from childhood and learned all that could be learned in Latin (Grant, 1974, p. 35). Although there are no detailed records of his life before he came to Toledo, one can deduce that his education and enthusiasm towards science were some of the key elements in his habitus. While none of these sources consulted gives any details regarding his education, it definitely involved astronomy since Ptolemy's astronomical work Almagest was why Gerard came to Toledo (Haskins, 1927, p. 286), where he learned Arabic to transmit the wisdom of the Arabs to the West. Sources differ on the date of his arrival to Toledo, ranging from 1130 to 1157 (Öztunalı, 2017, p. 1332; Lemay, 1985, p. 422; Delisle \& Woodsworth, 1998, p. 191). Furthermore, his interest in science cannot be limited to astronomy since he translated works on dialectic, geometry, philosophy, physics, medicine and mathematics (Turner, 1909; Lemay, 1985, p. 422). Therefore, it can be stated that he had already educated himself on diverse fields of science. Moreover, he provided comments while translating the works of Aristotle (Jordan, 1998, p. 3098), which proves that Gerard was well educated on philosophy since he did not only translate philosophical works that were not available in Latin, he was also able to provide commentaries on them. As it is clear, the major elements in Gerard's habitus, which 
played a crucial role in his journey to become a prolific translator on various topics, are his education, multilingualism and interest in diverse scientific fields.

\subsection{Capitals}

Another factor in the formulation of social action, which is also a determinant regarding one's position in the field, is the capitals. Bourdieu (1986) states that "it is in fact impossible to account for the structure and functioning of the social world unless one reintroduces capital in all its forms and not solely in the one form recognized by economic theory" (p. 15). From this point of view, it is necessary to discuss all types of capitals possessed by Gerard to fully understand his position in the field. Therefore, his cultural capital, symbolic capital, social capital and economic capital will be discussed in an effort to depict the whole picture.

Bourdieu (1986) proposes three forms of cultural capital: embodied, objectified and institutionalized. The embodied cultural capital takes "the form of long-lasting dispositions of the mind and body" (p. 17). The first component of Gerard's embodied cultural capitals is his knowledge of Italian, Latin and Arabic. Another one is his translation skills. As discussed previously, being one of the most prolific translators of the period, he was undoubtedly a good translator, otherwise his indirect translations would not be used even after the direct translations from Greek were published (Pym, 1998a, p. 142). Also, his knowledge of the subjects he translated can be considered as an embodied cultural capital. Jacquart (1992) states that Gerard gave astrology and astronomy classes to other translators and students of the Toledo School (as cited in Öztunalı, 2017, pp. 1332-1333). Furthermore, he knew which texts would constitute a body of knowledge, a curriculum in Latin if translated; in a sense, he was already educated in the subject before translating them into Latin (Jordan, 1998, p. 3098). As discussed previously, Gerard had knowledge in the subject of geometry and he translated some works on this topic. Aside from contributing to the Latin scholarship with his translations, he expanded the scope of geometry by including algebra into it, and moreover, he added perspective and statics which European scholars previously did not know (Burnett, 2001, p. 259). In his article, Burnett (2001) states that Gerard had a more precise program in terms of translations than other translators of the period and attributes this to "his knowledge of the Arabic philosophers' divisions of sciences along Aristotelian principles" (p. 260). In addition, Burnett (2001) indicates that Gerard's mathematical and medical translations both had a long-lasting influence on Western scholarship (p. 266). He must have had a substantial amount of embodied cultural capital in terms of knowledge on mathematics and medicine to accomplish this influence. Another type of cultural capital is objectified, which takes the form of cultural goods (Bourdieu, 1986, p. 17). Apart from his revisions of the texts previously translated by other translators, he translated 71 texts from authors like Ptolemy, Aristotle, Avicenna, Archimedes and Galen (Burnett, 2016, p. 191). His translated texts constituted one part of his objectified cultural capital, while the other part was composed of his own 
library, which, according to Lemay (1978), he left to the church of Santa Lucia in Cremona, Italy (p. 173). When his subject knowledge on diverse topics is considered, this library must have been extensive. Additionally, he traced, identified and collated his source texts (Lemay, 1985, p. 423), which might have been a part of this personal library. What Bourdieu (1986) refers to as institutionalized cultural capitals are academic qualifications (p. 20). As mentioned earlier, Gerard received his education in his country of birth, Italy. With this education, he obtained all the knowledge that Latin scholarship could offer and moved to Toledo for more. However, there are no records of Gerard's time in Italy. Therefore, it is disputable that his education in Cremona could be considered as an institutionalized cultural capital since it is unknown whether he completed an education program or earned a degree.

Bourdieu (1989) defines symbolic capital as "the power granted to those who have obtained sufficient recognition to be in a position to impose recognition" (p. 23). In other words, symbolic capital provides its possessor a recognition in the relevant field. Haskins (1927) states that Gerard was "the most industrious and prolific of all [the] translators from the Arabic" and "more of Arabic science in general passed into Western Europe at the hands of Gerard of Cremona than in any other way" (pp. 286-287). This statement alone proves Gerard's high amount of symbolic capital and puts him in a central position in the cultural field of the period. If we consider specific fields such as medical and astronomical scholarship, a similar outcome is observed. His contributions to the anatomical knowledge of the period confirm this. Gerard translated the Canon of Medicine by Avicenna, and this translation encouraged many figures who later became leaders in their field to study anatomy. Some of the terms he translated replaced the existing ones and some of them are still in use today, such as sagittal, diaphragm, orbit and pupil (Arráez-Aybar, Bueno-Lopez, \& Raio, 2015, pp. 25, 30, 32). His translation also became the principal textbook for medical studies between the $13^{\text {th }}$ and $17^{\text {th }}$ centuries (Burnett, 2016, p. 192). He was also the main translator of the works of Galen in the field of Western medical scholarship (Burnett, 2001, p. 266; Haskins, 1927, p. 324). Such presence in the field could be regarded as symbolic capital. Similarly, the Almagest translated by Gerard was the basis for the Latin names of the stars (Öztunalı, 2017, p. 1332), and as stated earlier, this indirect translation "continued to be read and revered" even after a direct translation from Greek into Latin became available (Pym, 1998a, p. 142). Thus, it is clear that Gerard also accumulated a substantial amount of symbolic capital in the field of Latin astronomical scholarship through his long-lasting translation of Ptolemy's work. Apart from being famous for his translation of astronomy, according to Weber (2019), Gerard was also one of the two translators who created an interest among Latin scholarship towards philosophy and natural science (p. 405). Similarly, Lemay (1985) claims that the interest of medieval universities in Greek and Arabic science and philosophy owes its stimulation for the most part to Gerard's work (p. 423). Gerard made long-lasting contributions to various fields through his translations. For that matter, the scholarly visitors of Toledo were keen on getting a copy of his works 
(Burnett, 2016, p. 191). All of these demonstrates that he was an active agent in diverse fields with significant recognition, i.e. symbolic capital.

Another type of capital is social. Bourdieu (1986) defines social capital as "the aggregate of the actual or potential resources which are linked to possession of a durable network of more or less institutionalized relationships of mutual acquaintance and recognition" (p. 21). In a sense, accumulating social capital can be interpreted as creating a network. We know that Gerard had students since, as mentioned above, he gave lectures and some of his students created a list of his translated works after his death in 1187 (Burnett, 2001, p. 254). Although they constituted a part of Gerard's social capital, their role is unknown. Lemay (1978) claims that they may have been responsible for retrieving Arabic source texts for him (p. 174). Another hypothesis proposed by Delisle \& Woodsworth (1998) is that Gerard translated Almagest with the help of a team (p. 191), which might well have consisted of his students. However, the only documented help that Gerard received while translating Almagest was from a Mozarab named Galippus (Burnett, 2001, p. 253). Another type of social capital possessed by Gerard came from an institution in his field, the church. The church's authority protected the works of translators who worked within it (Delisle \& Woodsworth, 1998, p. 132). In a sense, this institution created its own network and provided protection to its members. This was also an important social capital for Gerard. Together with his students, whether they retrieved the source texts or helped in the translation process, Gerard had some amount of social capital which facilitated his work.

Accumulating economic capital aims to maximize profit, it is "immediately and directly convertible into money" (Bourdieu, 1986, p. 16). Although it would have been useful to discuss Gerard's economic capital in this analysis, there is no record of his economic situation or the earnings from his translations. Furthermore, no source states an average price for translations in the period. However, being a prolific translator and being able to continue one's scholarly work require a certain amount of economic capital. Since Gerard's only occupation was translation, he must have earned at least the necessary income to be able to continue his translations.

\section{Conclusion}

The Bourdieuan analysis of Gerard above shows clearly how his background led him to leave his previous cultural field and enter into a new one, how he kept accumulating more cultural capital and how his habitus and capital together put him in a central position in various scholarly fields. If we were to place this analysis into Bourdieu's (1984) formulation of social action, "[(habitus) (capital)] + field = practice" (p. 101), Gerard's habitus retrieved all his previous field could offer in terms of education. Thus, in order to accumulate more cultural capital, he went to Toledo and entered a more prosperous cultural field with lots to offer. In order to translate the Arabic works in Toledo, he learned Arabic as an embodied cultural capital. He formed a network with his students which might have helped him in the process of translation. His knowledge of 
the diverse scientific subjects (his habitus) developed an interaction with his accumulated capitals; and since the general conditions of the field enabled, or perhaps required, transfer of knowledge, he became a translator of Arabic scientific and philosophical works. However, what made this possible was not the conditions of the field or his capitals alone. It was rather the combination of the two which created "a scarcity value" for the cultural capitals of Gerard in that period. Bourdieu defines (1986) "the scarcity value" as a large cultural capital that provides significant benefits to its possessor due to its rareness in the field, for instance "being able to read in a world of illiterates" (p. 18). Indeed, Gerard's embodied cultural capitals such as his knowledge of diverse scientific disciplines, his multilingualism, his fine translation skills were quite scarce in the field at the time. This scarcity value, together with the analysis of the cultural field in Toledo at the time and Gerard's habitus and capitals, not only explains how the period initiated a translation movement but also how Gerard came to the forefront of it. The results of this paper can contribute to the general study of translation history and fill a gap by using a Bourdieuan analysis in a study of translation and translator history, which creates an interdisciplinary field with translation studies and sociology. If this paper can be combined with sociological studies on other translators who came to Toledo in search of Arabic wisdom, such a study might show us a pattern, which would explain how a bilingual scholar became an important translator of the period. Furthermore, if a similar approach is adopted to investigate other important translation movements and their leading translators, this paper might help understand the conditions in which an intense translation movement occurs and how a person comes to be an important figure in the translation history and a prolific translator.

\section{Acknowledgements}

I would like to express my appreciation to Dr. Gülfer Tunalı for her constructive feedback during the development of this research. In addition, I am grateful to Assoc. Prof. Atalay Gündüz for making the complex thoughts of Pierre Bourdieu easy to understand and recommending further readings.

\section{References}

Arráez-Aybar, L., Bueno-Lopez, J., \& Raio, N. (2015). Toledo School of Translators and their influence on anatomical terminology. Annals of Anatomy, 198, 21-33.

Baker, M. (1998). Arabic tradition. In M. Baker (Ed.), Routledge encyclopedia of translation studies (pp. 316-325). Routledge.

Bourdieu, P. (1977). Outline of a theory of practice (R. Nice, Trans.). Cambridge University Press.

Bourdieu, P. (1984). Distinction: a social critique of the judgement of taste (R. Nice, Trans.). Routledge. 
Bourdieu, P. (1986). The forms of capital. In J. Richardson (Ed.), Handbook of theory and research for the sociology of education (pp. 241-258). Greenwood.

Bourdieu, P. (1989). Social space and symbolic power. Sociological Theory, 7(1), 14-25.

Bourdieu, P. (1993). Sociology in question (R. Nice, Trans.). Sage.

Bourdieu, P. (2005). The Social structures of the economy (C. Turner, Trans.). Polity.

Bourdieu, P., \& Wacquant, L. (1992). An invitation to reflexive sociology. Polity Press.

Burnett, C. (2001). The coherence of the Arabic-Latin translation program in Toledo in the twelfth century. Science in context, 14, 249-288.

Burnett, C. (2016). Gerard of Cremona. In T. F. Glick, S. J. Livesey, \& F. Wallis (Eds.), Medieval science, technology, medicine: An encyclopedia (pp. 191-192). Routledge.

Delisle, J., \& Woodsworth, J. (Eds.). (1998). Translators throughout the history. John Benjamins.

Gouanvic, J. M. (1997). Translation and the shape of things to come: The emergence of American science fiction in post-war France. The Translator, 3(2), 125-152.

Grant, E. (1974). The translation of Greek and Arabic science into Latin. In E. Grant (Ed.), A source book on medieval science (pp. 35-40). Harvard University Press.

Hanna, S. (2005). Hamlet lives happily ever after in Arabic: The genesis of the field of drama translation in Egypt. The Translator, 3(2), 167-192.

Hanna, S. (2016). Genesis of the field of drama translation in Egypt: The first Arabic Hamlet. In S. Hanna (Ed.), Bourdieu in translation studies (pp. 72-98). Routledge.

Haskins, C. H. (1927). The renaissance of the twelfth century. Harvard University Press.

Jordan, M. D. (1998). Gerard of Cremona. In E. Craig (Ed.), Encyclopedia of philosophy (pp. 30983099). Routledge.

Lemay, R. (1978). Gerard of Cremona. In Dictionary of Scientific Biography, 15 (pp. 173-192). Charles Scribner's Sons.

Lemay, R. (1985). Gerard of Cremona. In J. R. Strayer (Ed.), Dictionary of middle ages (pp. 422423). Charles Scribner's Sons.

Liu, J. (2012). Habitus of translators as socialized individuals: Bourdieu's account. Theory and Practice in Language Studies, 2(6), 1168-1173.

McVaugh, M. (1974). Gerard of Cremona. A list of translations made from Arabic into Latin in the twelfth century. In E. Grant (Ed.), A source book of medieval science (pp. 35-38). Harvard University Press.

Öztunalı, O. (2017). Toledo Çevirmenler Okulu'nda gerçekleştirilen çalışmaların kültürlerarası yeri ve önemi. DTCF Dergisi, 57(2), 1323-1339.

Pym, A. (1998a). Method in translation history. Routledge. 
Pym, A. (1998b). Spanish tradition. In M. Baker (Ed.), Routledge encyclopedia of translation studies (pp. 552-563). Routledge.

Sayols, J. (2018). Transculturation and Bourdieu's habitus theory: Towards an integrative approach for examining the translational activity of literary translators through history. Target, 30(2), 260-287.

Simeoni, D. (2007). Between sociology and history: Method in context and in practice. In M. Wolf, \& A. Fukari (Eds.), Constructing a sociology of translation (pp. 187-204). Benjamins.

Sungu, i̇. (1940). Tercüme ve renaissance. Tercüme, 1(2), 115-119).

Turner, W. (1909). Gerard of Cremona. The Catholic encyclopedia. Robert Appleton Company. http://www.newadvent.org/cathen/06468a.htm

Vosloo, F. (2007). 'Inhabiting' the translator's habitus: Antjie Krog as translator. Current writing: Text and reception in Southern Africa, 19(2), 72-93.

Weber, M. (2019). A Muslim's book and its Christian and Jewish readers: The way al-Farabi's Enumeration of the sciences came to influence Western European scholars. In M. T. Abate (Ed.), Convivencia and medieval Spain (pp. 393-408). Palgrave Macmillan.

Weber, M. W. (2002). Gerard of Cremona: the danger of being half-acculturated. Medieval Encounters, 8(2-3), 123-134. 